\title{
THE EMPLOYER RESERVE TYPE OF UNEMPLOYMENT COMPENSATION LAW
}

\author{
Elizabethe Brandeis*
}

Under the impetus of Title IX of the Social Security Act we hope for the rapid spread of state unemployment compensation laws. ${ }^{1}$ The form these laws will take depends in large measure on decisions to be made in the several states. The federal standards are few in number. In addition to many questions of detail, each state must decide two basic questions: (I) Who should contribute to the unemployment compensation fund: employers only, or employees (and perhaps the state) as well? (2) How should the fund be set up: on an employer reserve basis; or as a state-wide insurance pool, with or without some provision for merit rating? The first of these questions is fully treated elsewhere in this symposium. This paper is addressed to the second question. After stating briefly the essential differences between the two systems, it will discuss the purposes of unemployment compensation and explain why in the writer's opinion these purposes can best be served by an employer reserve set-up. The rest of the paper will be devoted to an analysis of the special problems arising under that system, and the ways in which and the extent to which these problems can be solved.

\section{Major Differences Between Reserve and Pool Systems}

The essential elements of the employer reserve system are three. First, employers alone contribute to the fund-there are no contributions from employees or the state. ${ }^{2}$ Second, the contributions of each employer, though mingled with those of others for safe-keeping and investment purposes, are kept distinct like an account in a bank, and can be used only to pay benefits to his own laid-off employees. Third, the rate

- B.A., I9I8, Radcliffe; M.A., I924, Ph.D., I928, University of Wisconsin. Instructor, Department of Economics, University of Wisconsin, teaching course in Labor Legislation. Formerly Secretary of District of Columbia Minimum Wage Board. Vice President, National Consumers' League. Author: History of Labor in the United States, Vol. 3, Pt. II, Labor Legislation.

${ }^{1}$ Nine such acts were passed in 1935 .

${ }^{2}$ It may be said that this is an arbitrary definition, that employee contributions are not incompatible with a reserve set-up. It is the writer's contention that they violate the theory on which it is based. Moreover they would create serious administrative difficulties. The draft reserve bill put out by the Social Security Board contains an optional provision for employee contributions, but appends the following note: "Contributions by employees may cause inequities if paid into separate employer accounts. If a state desires to include employee contributions in a law of the reserves type, employee contributions should be paid into the fund's "pooled account." See Soc. Sec. Bd., Draft Reserve Bill, note, p. 20. This in effect would constitute a partial pool, to that extent a departure from the reserve system. 
of contribution of each employer varies directly and automatically with the size of his reserve account. His reserve balance at any time depends of course on the amounts which he has paid out in benefits to workers whom he has laid off. To the extent to which he keeps his workers steadily employed there is no drain on his reserve and it accumulates. When his reserve shows an adequate balance (over and above his current benefit costs) he is permitted to decrease or even suspend his contributions. On the other hand, if unemployment in his plant makes heavy calls on his reserve and reduces it below a given safety point he will be required to contribute at a higher rate. ${ }^{3}$ Under the draft reserve bill prepared by the Social Security Board the employer's contribution rate may vary from zero to $3.6 \%$, the standard rate being $2.7 \%$.

In contrast to the employer reserve system, a pooled insurance set-up: ( $\mathrm{r}$ ) may include contributions from employees and the state, as well as from employers; (2) mingles all contributions in one fund, from which benefits are paid to all laid-off employees regardless of their previous employer; (3) may, or may not, provide for varied employer contribution rates under some kind of "merit rating." That is, provision may be made for certain reductions or increases in employer contribution rates, on the basis of their unemployment records. However, under pooled plans the difference in contribution rates as between employers will never equal their difference in regularity of operations. ${ }^{4}$ If it did, the pooled character of the system would be destroyed. The object of pooling is to "spread the risk." This really means that employers who provide steady work will help to pay benefits to the laid-off workers of employers who fail to do so. Those employers who operate irregularly will not put enough in the pool to protect their workers. The deficit will be made up by the steady employers who will contribute more than is needed to protect their workers. ${ }^{5}$

\section{Employer Reserves and the Purposes of Unemployment Compensation}

The choice between these alternative methods of setting up an unemployment compensation fund cannot be made intelligently without considering the purposes

'This provision is lacking in the Utah reserves law, but clearly is needed to make the reserve set-up self consistent. It was added to the Wisconsin law by amendment in 1935. See Wis. STAT. (I935) $\$ 108.18$ (2).

None of the pool laws so far enacted in this country permit a reduction in employer contribution rates below $.7 \%$. Several laws even set a $1 \frac{1}{2} \%$ or $2 \%$ minimum. See Ala. Laws, I935, Sen. B. No. 395, $\$ 4$ (c); Dist. of Col., Public, No. 386, 74th Cong., Ist Sess. (r935) \$3 (b); Wash. Laws 1935, c. I45, $\$ 5(4)$.

The probable limitations on merit rating under a pool system were stated recently by the Industrial Commissioner of New York as follows: "Under a merit rating system employers with slight labor turnover, or perhaps entire industries, might have rates of contribution reduced somewhat. However it is my strong feeling that such reductions should not be more than enough to provide employers with an incentive to stabilize employment. . . . The basic principle of the exclusive state fund is that all employers and all industries are to be made generally responsible for the accumulation of the monies to be paid out as benefits to the eligible unemployed. . . Should large deductions be permitted, the foundation of the State Fund would be impaired." Speech of Elmer F. Andrews, Dec. 4, 1935, from release by N. Y. State Dept. of Labor, Dec. 5, 1935. 
which this legislation is designed to serve. If it is intended merely for the payment of out-of-work benefits to unemployed workers, the only criterion for judgment is the adequacy of the benefits which can be provided. But surely this is an oversimplification of the problem, based on a sadly defeatist attitude. In the United States we should not regard unemployment compensation as just one kind of social insurance; but rather as part of a comprehensive social security program, of which the Federal Act itself is only one installment. The wider term has been chosen in America because we have embarked on the more daring and ambitious quest. In our effort to protect wage earners from the economic hazards to which they are exposed, we are not content with merely providing a partial substitute for their wages, when for one reason or another they are deprived of the ability or opportunity to earn a living. We recognize that such substitute income is necessarily inadequate and otherwise unsatisfactory. We are trying, so far as possible, to give security to wage earners by reducing the economic risks which they must run. Unemployment is the most serious of these risks. A satisfactory program for enhancing security against unemployment must include both an attempt to reduce the hazard to its smallest possible proportions, and provision for compensating the unemployment that remains. This twofold purpose has been repeatedly stated by organized labor, by representative employers, and by high government officials.

Our question then becomes: Which system of compensation will best serve this twofold purpose-employer reserves or pooled insurance?

It is obvious that the focal point of attack on unemployment is the individual employer. $\mathrm{He}$, if anyone, can prevent it, by keeping workers steadily employed. Of course conditions beyond his control may make this impossible. The catastrophes of severe depression may force him to close down his plant entirely, regarcless of the cost, to avoid even greater losses. Technological change may sometimes be so irresistible that he cannot stay in business if he does not introduce automatic machinery which necessitates permanent reductions in his working force. But many shut-downs, even in time of depression, and many lay-offs, even due to technological change, involve close calculations of relative gains and losses. This is even more true of shut-downs and lay-offs due to seasonal fluctuations or other variations within the normal year. If lay-offs are made to involve new increased costs, it is reasonable to suppose that employers will in many instances manage to devise ways to avoid them.

The employer reserve system is a device for allocating to the individual employer the cost of his own lay-offs and no one else's. It assures that his contribution for unemployment compensation will reflect his own success or failure in giving steady jobs. Hence it gives him a clear-cut, definite incentive to stabilize his operations. On the other hand, if industry in general through a pooled fund assumes the cost of compensating the unemployed, there will be no incentive for the individual employer. Quite the contrary. If all employers contribute equally, regardless of the 
stability or instability of employment in their individual plants, none of them will have any inducement to attempt more regular operation-since those who did would merely be carrying the cost of compensating workers laid off by others, possibly their keenest competitors. ${ }^{6}$

Even as regards unemployment which cannot be avoided, it is important that its cost should be allocated to the particular concern which was its proximate cause, rather than carried by industry in general through a pooled fund. Maintaining the unemployed is a social cost which must be carried in some way. But an equal sharing of the burden means in effect that stable employers are subsidizing the concerns which operate irregularly. This creates a species of competition which is both unfair and anti-social in character, because it may force out of business the more stable concerns and thus actually increase irregularity of employment and the social cost it creates.

This is the argument for employer reserves. It cannot be lightly dismissed as academic or utopian. For it is the argument of practical business men, some of whom have voluntarily tried out such reserves as part of a serious attempt to eliminate unemployment in their own concerns. The spokesman for these employers, when the Social Security Bill was before Congress, was M. B. Folsom of the Eastman Kodak Company, which "has been working on stabilization methods for 35 years and as a result shows comparatively little fluctuation in employment in normal years though faced with a very difficult seasonal fluctuation in sales."7 Mr. Folsom submitted a carefully prepared statement to the Senate Finance Committee. Speaking apparently for the employer members of the Advisory Council appointed by the President to the Committee on Economic Security, Mr. Folsom said:

"We realize that there is a decided difference of opinion as to the two principal systems of unemployment compensation-the pooled system and the separate account system. Many of the experts and those who are approaching the subject from a theoretical point of view favor the pool. . . . These experts . . . contend that individual employers cannot do anything about reducing the fluctuations of employment and that there is thus no need for offering an incentive to stabilization. . . Those who contend that nothing can be done about stabilization have in most cases had no practical experience. The companies with unemployment benefit plans in operation all state that they do serve as a strong incentive to stabilize. This has been the case in Rochester. ${ }^{8}$ Even those companies which previously had a good record in employment stabilization have found that they could do a better job. ... We feel that if the employer has an incentive, and the only incentive which really counts is the possible reduction in his rate, the great majority of employers can do a better job than they have done and that much steadier work will be provided to

\footnotetext{
- For a discussion of merit rating under a pool plan and its limitations in affording an incentive to regularization, see pp. $63-64$, infra.

'Statement of M. B. Folsom, U. S. Senate, Committee on Finance, Hearings on S. IIzo (Economic 'Security Act), 74th Cong. Ist Sess., Jan. 22-Feb. 20, 1935, p. 581.

Rochester, N. Y., where seven companies started paying benefits under voluntary unemployment sescrve plans in January, 1933.
} 
a great many workers. ... The employers on the Advisory Councilo do not take the defeatist attitude that nothing can be done, but ask that industry be given some incentive to reduce unemployment."

As for the effect of a pool plan, Mr. Folsom points out briefly the likelihood that it will actually increase unemployment:

"The straight pool system, under which all employers contribute at the same rate cannot serve as an incentive to stabilize. On the other hand it will change the whole employment policy of a company and will undoubtedly result in greater layoffs during the early stages of a depression. There will be no incentive for a company to spread employment and when it is necessary to curtail production the least efficient workers will be laid off immediately and the other workers kept on full time. The actuaries we understand have assumed that under a pool plan an allowance must be made for an increase in unemployment."10

So much for the general argument for the employer reserve system. We must next consider whether it creates special problems and difficulties not found in the pool system, and how such problems can be solved.

\section{Spectal Problems of Employer Reserves}

\section{Exhaustion of Reserves}

The most obvious problem raised by an employer reserve law is the possible exhaustion of the reserves of some employers. Reserve laws and bills recognize and deal with this problem in several ways. Typically they provide that benefits shall continue to be paid from an employer's account as long as there is any money in his reserve. ${ }^{11}$ In any week when there is not enough money left to pay all claims in full, benefits will all be scaled down; or if nothing is left, nothing will be paid. The employer's next contribution will enable benefits payments to be resumed to the extent that money is then available. ${ }^{12}$ This arrangement should be reasonably simple to operate and sufficiently equitable. The workers first laid off by a given employer should stand the best chance of drawing their full benefits; the others will have had the advantage of holding their jobs longer.

The arrangement for scaling down or suspending benefit payments when reserves become exhausted does not, of course, solve the more fundamental problem of protecting the workers against the loss of compensation. The real solution is not a reduc-

'These employers were M. B. Folsom, Eastman Kodak Co., M. E. Leeds, Leeds \& Northrup, S. Lewisohn, Miami Copper Co., Gerard Swope, General Electric Co., and W. C. Teagle, Standard Oil Co. of N. J.

${ }^{10} \mathrm{U}$. S. Senate, Hearings, stupra note 7, at pp. 583-584.

${ }^{11}$ The Wisconsin act as originally passed contained complicated provisions for a gradual scaling down of benefit payments beginning when the reserve fell below a certain (rather high) point. Sce Wis. STAT. (1933) \$108.06 (4). The arrangement was calculated to stretch out payments over a very long period and to make complete exhaustion of the reserve improbable. This was done on the theory that suspension of benefit payments would be unjust, because it would mean that the employees first laid off would get all the money in the reserve and leave nothing for those laid off later. By amendment this system for scaling down benefits has been abolished.

${ }^{12}$ See Wis. Stat. (1935) \$ro8.06 (4) (Wis. Laws 1935, c. 192). 
tion in benefits, but an increase in contributions. The employer whose irregularity of employment so exceeds the average that his reserve approaches exhaustion should obviously be required to contribute at substantially above the "standard" rate. The Wisconsin Act (as amended in I935) specifies:

"If the benefits paid from his [any employer's] account within the calendar year just ended were greater than his contributions for such year, his rate [for the next calendar year] shall be increased by one half per cent on his payroll but shall never exceed one and one half times the standard rate. . .."13

This increase in contribution rate will probably not be enough even in normal times to protect every reserve against depletion, but it is a step in that direction. After a few years of operation very irregular concerns may well be called upon to pay considerably higher contribution rates. It is obvious that the present range in contribution rates under the Wisconsin unemployment compensation act (or the draft reserve bill) is not nearly so great as the prevailing range in premium rates under accident compensation laws. Why should not the range be at least commensurate? The variation in hazard is probably as great, and the reserve system should not be afraid to go as far as insurance companies do in differentiating contributions on the basis of risk and cost. ${ }^{\mathbf{1 4}}$

Critics of the reserve plan may assert that even a much wider range in contribution rates will not save some reserves from exhaustion, particularly in the event of a depression. In reply it might be suggested that even a state-wide pool may well become exhausted at such a time, with perhaps more serious consequences. ${ }^{15}$

\section{2. "Actuarial" Difficulties}

Related to the problem just discussed is that of determining what benefits a given standard contribution rate can finance. For pool plans elaborate actuarial calculations have frequently been attempted. But the results are admittedly very rough estimates-as much of the needed data is lacking. It is sometimes said that this problem is even more difficult of solution under a reserve plan. This is undoubtedly true. The ideal goal to be sought is such a relation between contributions and benefit rates that the average employer will, by paying the standard rate of contribution, finance a reserve normally adequate to pay the stipulated benefits. Concerns operating more irregularly than the average will be required to contribute at higher rates. Employers who do better than average in providing steady jobs will be able

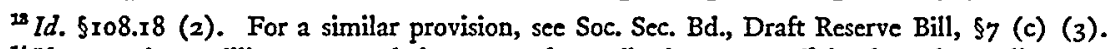

II If a state is unwilling to extend the range of contribution rates sufficiently to keep all reserves solvent in normal times, it is possible to set up a "partial pool" to which all employers contribute a small amount, say $1 / 2 \%$-this pool to be used only to pay supplemental benefits when reserves become exhausted. A very small pool of this sort is provided for under the draft reserve bill, to be made up of realized earnings on investments and balances Ieft in the reserves of employers going out of business. See Soc. Sec. Bd., Draft Reserve Bill, $\$ 9$ (g).

${ }^{25}$ The desire to protect the pool in normal times may lead to general inequities, similar to those created by the exhaustion of the reserves of the least stable concerns. For many of the pool laws severely limit the right to benefits of seasonal workers or exclude seasonal and casual employment entirely. See, for example, N. Y. Laws 1935 , c. $468, \$ 509$, Mass. Laws 1935, c. $479, \$ \$ 26,28$. 
to contribute at less than the standard rate, or may be able to suspend payments entirely. Of course this statement does not answer the immediate question of how many benefit weeks can be financed from a $2.7 \%$ standard contribution rate. Fortunately under the reserve system it is unnecessary to attempt more than a rough guess in this matter. Employees are promised benefits only so long as the reserves of their employers remain adequate to pay them. If the reserves of some employers become exhausted, that should not discredit the entire system. If this condition became general there would no doubt be pressure on the legislature both to raise the standard contribution rate, and to provide for a greater step-up. But a reserve law, far better than a pooled fund, can start without the actuarial foundation which in this country it is in any case impossible to secure.

\section{Effect on Mobility of Labor}

Employer reserves are sometimes criticized for their alleged interference with mobility of labor. It is charged that because the worker draws benefits only from the account of his own employer, he will be tied to his job. This criticism of employer reserves is derived from the operation of private welfare plans for group insurance, retirement pensions, etc. These plans have certainly had the effect charged, in fact in most instances they were largely designed for this purpose. Their terms were drawn to prevent labor turnover. It has been loosely assumed that similar terms would be a necessary part of an employer reserve law. This assumption is clearly fallacious. ${ }^{16}$ Such terms are no more necessary under a reserve law than under a pool plan. In the two draft bills prepared by the Social Security Board (one providing for a pool, the other for employer reserves) the provisions which might affect mobility of labor are identical. Unemployment compensation will only operate to reduce mobility of labor if the worker who quits voluntarily or goes on strike loses accumulated rights to benefits. In both the draft bills no benefits are payable while a strike is in active progress; ${ }^{17}$ voluntary quitting is penalized only by a disqualification period during which no benefits are payable. ${ }^{18}$ Under neither bill are accumulated rights to benefits entirely lost. ${ }^{10}$ It may be said

${ }^{1 s}$ Equally fallacious is the assumption sometimes made that employer reserves will lead to company unions. Company unions can hardly gain from laws which provide for the decision of disputed benefit claims by impartial government agencies; especially when organized labor participates actively in administration through representation on appeal boards and advisory committees-as is provided in both the Utah and Wisconsin acts. Such participation has been an acknowledged fact in Wisconsin since 1932. See Wis. Stat. (1935) $\$ 108.09$ (4), I08.14 (5) and Utah Laws 1935, H. B. No. 86, $\$$ I4, 27 (b).

${ }^{17}$ This is true under all American laws.

${ }^{18}$ It must be admitted that employers under a reserve plan may object to this provision as to voluntary quitting, on the ground that it is unfair to require them to pay benefits to workers whom they were willing, perhaps anxious, to retain in their employ. But this objection may also be heard under a pool system, if it contains bona fide merit-rating provisions (such as those in the New Hampshire law). If an employer under a pool plan is really interested in his record he too may resent having this kind of unemployment count against him. Perhaps some arrangement might be devised under a pool plan by which the employee who quit could receive benefits without such benefits counting to the demerit of the employer whom he left. To the writer's knowledge no such arrangement has yet been worked out or enacted.

${ }^{10}$ See Soc. Sec. Bd., Draft Reserve and Pooled Fund Bills, $\$ 5$ (a). 
that mobility will be slightly discouraged under both bills. ${ }^{20}$ The charge against the reserve system as such can be dismissed.

\section{Permissive or Mandatory Pooling}

The question is often raised whether a reserve system should permit or require certain groups of employers to pool their accounts. As for permissive pooling, in cases where it can be shown that it will conduce to regularization, it should be allowed. It may be noted that virtually no requests to pool accounts have been made under the Wisconsin law to date.

Mandatory pooling is often suggested as necessary for the protection of employees in an industry with many very small concerns. But why should such pooling be necessary? The administrative problem of keeping a large number of small reserve accounts is no greater than keeping track of many small employers contributing to a pool. Small reserves are of course just as adequate (relatively) as large onesit is obviously a matter of relation to payroll. There is no reason to think that unemployment is greater in small concerns than large ones-probably the reverse is true. It is sometimes argued that small concerns may escape the notice of the enforcing agency and may never set up reserves at all and that some pool should protect their employees. The remedy for this situation is preventive vigilance by the enforcing agency, and by the workers affected.

\section{Should the Reserve System Permit "Exempted Plans"?}

Because exempted plans have played a large part in the Wisconsin picture in the past, it may be asked whether there are any good reasons why reserve systems elsewhere should permit them. (It is unnecessary to discuss here the special circumstances which made "exemption" so important in Wisconsin prior to the enactment of the Federal Act.) Since the standard provisions of a reserve law treat each employer according to his own record, "exemption" can hardly be justified, unless the employer will thereby provide conditions more beneficial to his employees than the state reserve system. ${ }^{21}$

\section{Administrative Problems Created by the Reserve Set-up}

There remain a number of more strictly administrative problems inherent in the reserve system.

${ }^{n}$ For more serious loss of benefit rights in case of voluntary quitting see the provisions in the Washington (pooi) law, Wash. Laws I935, c. I45, \$7 (5) and the Wisconsin (reserve) law, Wis. Stat. (r935) \$108.04 (4m) (b).

${ }^{2}$ Private financial handling of an exempted employer's reserve fund, even if it were permitted under the Social Security Act, would clearly seem less beneficial to employees than deposit in a central state fund. It is often urged that a reserve plan should permit employers in especially strong financial condition to maintain "bookkeeping reserves" (probably collateralized at least in part). This seems at first sight analogous to self insurance under accident compensation and desirable for the same reasons. But actually the social advantage of self insurance (the maximum incentive to prevention) is attained by the reserve system as a whole and this special arrangement is unnecessary. Moreover the dangers of a bookkeeping reserve are greater than those of self insurance in the accident field. For a heavy demand for cash to pay unemployment benefits is far more likely to coincide with a cash stringency than is the case in accident compensation. 
(a) Supposedly, the reserve plan is especially complicated, because it must specify some definite sequence in which an employee's successive employers shall become liable to finance his benefits. A very similar problem exists under a pool plan, however. For benefits must in any case be charged against weeks of previous employment. ${ }^{22}$ The only question is which weeks of employment should be charged off first in paying out benefits: the earliest weeks (not already used up), or the most recent weeks? Under the Social Security Board's draft bills there is no difference here between the pool and reserve plan. Benefits are charged to weeks of previous employment "in the inverse chronological order in which such weeks occurred." This means that under the reserve plan, if a laid-off worker has had two or more employers, the most recent employer is liable first. When his reserve has paid all its assigned quota of a worker's benefits, then the next previous employer becomes liable, etc.

(b) This liability first of one employer and then of another does create several administrative problems not found under a pool system. In the first place the weekly benefit rate to which a given worker is entitled may change when he uses up his right to benefits from his most recent employer, and begins to draw benefits from a previous one. Benefit rates under American laws whether pool or reserve are a percentage of full time weekly wages (limited by minimum and maximum amounts). ${ }^{24}$ This necessitates a determination of "full time hours" and hourly earnings for the individual laid-off worker, before his benefit rate can be fixed. The computations must be made under either a pool or a reserve set-up; but under a pool plan employment by different employers can be lumped together in making the computation, and one average figure can be arrived at. Under a reserve plan the figures must be computed separately for employment by each employer. The difference would not appear to be great.

(c) Similarly the cause of termination of employment may have to be reëxamined, when a worker exhausts his right to benefits from one employer and can draw benefits if at all only from an earlier one. If the particular reserve law bars him completely from benefits from a given employer, when discharged by that employer for misconduct or quitting him voluntarily, then the facts on these matters may have to be redetermined and his claim to further benefits may be disputed. But if, as under the draft reserve bill, the penalty in such cases is merely a period of disqualification for receipt of benefits, the question need hardly ever arise as that period would probably have run.

(d) Under a reserve plan it is customary to set up a probationary service period of four weeks or so, during which a new employee accumulates no rights to benefits-

\footnotetext{
$\approx$ This assumes that duration of benefits depends on a ratio to previous employment, as it does in all American unemployment compensation laws.

${ }^{23}$ See Soc. Sec. Bd., Draft Reserve and Pooled Fund Bill, $\$ 3$ (d).

is This is quite unlike British procedure which sets flat benefit rates regardless of previous wages. It is in accordance with American accident compensation legislation.
} 
on the theory that the employer should not be penalized for dismissing a worker proved by a reasonable trial to be unsatisfactory. ${ }^{25}$ Such a provision may seem an additional complication of a reserve law. In point of fact it really should be included in any pool law which takes merit rating seriously. Or else, if the worker accumulates rights to benefits during such period, it should not be charged against the employer. For he should have the same right as the employer under the reserve law to try out new workers without having it count against him if he dismisses them within a reasonable period.

(e) One other administrative complication may arise under the reserve plan, namely the problem of compensating a worker who has been concurrently employed by two or more employers and is laid off by one but not all of them. Space forbids adequate discussion of this problem here. Some method of defining partial unemployment and allocating liability in such cases will have to be worked out-probably by administrative rules. It cannot be said to constitute a major difficulty in any case.

\section{Special Advantages of a Reserve Set-Up}

Offsetting these special problems arising under the reserve system we can mention several definite practical advantages which it possesses in comparison with a pool fund.

The reserve system assures a definite party in interest to contest questionable claims for benefits and find jobs for laid-off workers if in any way possible. On the other hand an employer has no interest in protecting a "straight" pool against unjust claims from his former employees. He may even help them to get the largest benefits they can-feeling that he wants to get his money's worth for his contributions. The state agency is left with the whole burden of sifting dubious claims and also of finding jobs for the unemployed. It must assume two rôles-party to the dispute, and judge. In actual administration this may prove to be an important advantage of the reserve system.

Of course if a pool has bona fide merit-rating provisions, the difficulty just suggested will be overcome in part. The employer will then be interested in protecting his own record and indirectly the pool. But merit rating creates many difficulties of its own. So far only one definite method of achieving merit rating has been set forth; namely that in the New Hampshire and California laws. Provisions in other statutes are merely directions to the administrative agency to classify employers in accordance with their benefit experience and adjust their contribution rates accordingly. The New Hampshire and California laws say how this benefit experience is to be measured; namely by setting up a "paper" account for each employer against which benefits paid to his employees are to be charged. His contribution rate is to be determined on the basis of a theoretical balance in his account, a definite contribu-

\footnotetext{
z This probationary period should of course be a "once for all" proposition. See WIs. STAT. (I935) $\$ r 08.04$ (9). An employer cannot be permitted to escape liability by repeatedly taking on a given worker and then dismissing him at the end of the probationary period.
} 
tion scale being specified. ${ }^{26}$ This kind of merit rating (or any other) is bound to create many of the complications to be found in the reserve system. For most of these complications arise from the necessity of allocating responsibility to a definite employer each time a worker draws benefits. The same allocation (with similar complications) is necessary under merit rating to assure any real pressure toward prevention.

However, merit rating cannot in the nature of things give employers as clear-cut and definite an inducement to regularize as can a reserve set-up. A pool with merit rating is essentially a hybrid, with the defects of a hybrid. It cannot give the employer an unqualified promise that he will get the full benefit of his own performance in stabilizing employment. For the condition of the pool as a whole cannot or will not be disregarded. This dilemma is clearly shown in the automatic merit-rating provisions of the Social Security Board's draft pool bill. These provisions follow the New Hampshire example of setting up a paper account against which to measure the employer's own benefit experience. But they provide that every employer must always pay a minimum rate of at least $.9 \%$. More significant is the following proviso:

"No employer's rate for the period of twelve months commencing January I of any calendar year shall be less than $2.7 \%$ [the standard rate] unless the total assets of the fund ... exceed the total benefits paid from the fund within the last preceding calendar year and no employer's rate shall be less than $x .8 \%$ unless such assets at such time were at least twice the total benefits paid from the fund within the last preceding year."27

This provision documents and foreshadows the fact that under a pool plan merit rating will tend to be sacrificed to the necessities of the pool. Such provisions may well render illusory the incentive to employers claimed for merit-rating plans.

To sum up very briefly the contents of this paper: Unemployment compensation worthy of a place in a constructive security program must have a twofold purpose. The employer reserve type of compensation law seems better adapted to serve that purpose than any form of pool, and its special difficulties appear neither excessive not insuperable. No other form of merit rating will prove equally effective.

${ }^{20}$ See N. H. Laws 1935, c. 99, \$7; Cal. Stat. 1935, c. 352, \$39.

${ }^{n}$ See Soc. Sec. Bd., Draft Pooled Fund Bill, $\$ 7$ (c) (3). 